\title{
Purification and Some Properties of the Extracellular $\beta$-o-Glucosidase of the Cellulolytic Fungus Trichoderma koningii
}

\author{
By THOMAS M. WOOD* AND SHEILA I. MCCRAE \\ Department of Microbial Biochemistry, Rowett Research Institute, Bucksburn, \\ Aberdeen AB2 9SB, U.K.
}

(Received 1 March 1982; revised 13 May 1982)

The $\beta$-D-glucosidase which was associated with the cellobiohydrolase and endo- $(1 \rightarrow 4)-\beta$-Dglucanase activities in the cellulase of the fungus Trichoderma koningii was purified by gel filtration on a column of Ultrogel AcA 44, ion-exchange chromatography on DEAE-Sepharose and sulphoethyl-Sephadex (SE-Sephadex), and finally by isoelectric focusing in a $\mathrm{pH}$ gradient supported in a sucrose density gradient. The separation of $\beta$-glucosidase and endo- $(1 \rightarrow 4)-\beta$ glucanase, which was effected with some difficulty on SE-Sephadex, could be achieved readily by chromatography on a column of concanavalin A-Sepharose. Isoelectric focusing yielded two $\beta$-glucosidase components (pI 5.53 and 5.85) of identical molecular weight (39800), but with different affinities for $o$-nitrophenyl- $\beta$-glucoside $\left(K_{\mathrm{m}} 0.37 \pm 0.04\right.$ and $\left.0.85 \pm 0.03 \mathrm{mM}\right)$, cellobiose $\left(K_{\mathrm{m}} 1.18 \pm 0.09\right.$ and $\left.0.86 \pm 0.02 \mathrm{mM}\right)$, cellotriose $\left(K_{\mathrm{m}} 5.10 \pm 0.22\right.$ and $7.10 \pm$ $0.33 \mathrm{mM})$, cellotetraose $\left(K_{\mathrm{m}} 2.38 \pm 0.14\right.$ and $\left.4.0 \pm 0.4 \mathrm{mM}\right)$ and cellopentaose $\left(K_{\mathrm{m}} 1.51 \pm 0.04\right.$ and $2.19 \pm 0.06 \mathrm{~mm})$. One of the $\beta$-glucosidases was devoid of carbohydrate, the other contained approximately $2 \%$ carbohydrate. Gluconolactone was a powerful inhibitor of the action of both enzymes on $o$-nitrophenyl- $\beta$-glucoside $\left(K_{\mathrm{i}} 1.8 \pm 0.08\right.$ and $\left.1.17 \pm 0.05 \mu \mathrm{M}\right)$; glucose was less effective $\left(K_{\mathrm{i}} 1.05 \pm 0.07\right.$ and $\left.0.66 \pm 0.04 \mathrm{mM}\right)$. Inhibition was of the competitive type in each case. Both $\beta$-glucosidases showed the same capacity for acting in synergism with a mixture of the endo-( $(1 \rightarrow 4)-\beta$-glucanase and cellobiohydrolase in solubilizing the cellulose in cotton fibre. They differed markedly, however, in the degree of synergism they showed when acting in concert with the cellobiohydrolase on partially degraded $\mathrm{H}_{3} \mathrm{PO}_{4}$-swollen cellulose.

\section{INTRODUCTION}

The cellulases synthesized by the cellulolytic fungi Trichoderma koningii (Wood, 1972), Trichoderma reesei (Berghem et al., 1975; Gong et al., 1979), Penicillium funiculosum (Wood \& McCrae, 1977a) and Fusarium solani (Wood \& McCrae, 1977a,b) consist of three principal types of enzyme, namely, exo-( $1 \rightarrow 4)-\beta$-glucanase (cellobiohydrolase), endo- $(1 \rightarrow 4)-\beta$-glucanase and $\beta$ glucosidase. Detailed studies on the purified enzymes have established that when acting separately these enzymes have little or no action on highly ordered cellulose, but when together act synergistically to extensively solubilize the most refractory cellulosic materials. Two types of synergism seem to operate during the enzymic degradation. In the first stage of the reaction an enzyme A (endo-( $1 \rightarrow 4)$ - $\beta$-glucanase) produces a reactive product for enzyme B (cellobiohydrolase) while in the second stage an enzyme $C$ ( $\beta$-glucosidase) removes the inhibitory product (cellobiose) of the action of the other enzymes. The $\beta$-glucosidase enzyme is obviously an important component of the cellulase system and it has attracted much interest in recent years.

Trichoderma species seem to be the best sources of extracellular cellulases that can solubilize highly ordered cellulose, and they have been studied widely because of their potential importance in the industrial saccharification of cellulose. Unfortunately Trichoderma species, particularly $T$. reesei, are relatively poor synthesizers of $\beta$-glucosidase, and this has resulted in 
attempts by some to improve the performance of the cellulase by supplementation with $\beta$ glucosidase from other sources (Sternberg et al., 1977) or by the isolation of mutants that can produce higher yields of the enzyme (Beja da Costa \& van Uden, 1980).

In view of the commercial importance of $\beta$-glucosidase a better understanding of the enzyme is required. In this report we describe the purification and some properties of the $\beta$-glucosidase of Trichoderma koningii.

\section{METHODS}

Materials. The sources of the materials were as follows: $O$-carboxymethylcellulose sodium sait CellofasB (CMcellulose), ICI, Nobel Division; Texas-cotton fibre, Shirley Institute, Manchester, U.K.; Sephadex G-25, DEAESephadex and sulphoethyl-Sephadex (SE-Sephadex), Pharmacia; Ampholine carrier ampholyte and Ultrogel, LKB Instruments; D-glucose oxidase (type II), arbutin, phloridzin, salicin and amygdalin, Sigma; peroxidase, Boehringer; collodion tubes (Sartorius), V. A. Howe, London, U.K.; cytochrome $c$ (type II), $\alpha$-chymotrypsinogen (type II) and thyroglobulin (type II), Sigma; bovine $\alpha$-globulin, Armour Pharmaceutical Co., Eastbourne, Sussex, U.K.; and $o$-nitrophenyl- $\beta$-glucoside, BDH. Ovalbumin was a gift from Dr J. Conchie, Rowett Research Institute. All other reagents were of analytical reagent grade.

Preparation of $T$. koningii cellulase. Cultures and cell-free enzyme preparations were prepared from $T$. koningii IMI 73022 by batch culture as already described (Wood, 1968). The crude cell-free culture filtrate contained $41 \cdot 2$ units $\beta$-glucosidase activity $\mathrm{ml}^{-1}$. Concentrated (100-fold) and partially purified [20-80\% saturated $\left(\mathrm{NH}_{4}\right)_{2} \mathrm{SO}_{4}$ fraction] cell-free culture filtrate contained 4100 units $\beta$-glucosidase $\mathrm{ml}^{-1}$. A unit of activity is defined as the amount of enzyme needed to liberate $25 \mu \mathrm{g} o$-nitrophenol under the conditions of the assay described by Wood (1968).

Preparation of cello-oligosaccharides. Cello-oligosaccharides were prepared by the acetolysis (Miller et al., 1960) of cellulose powder (Whatman CC41), and separated by gradient elution ( 0 to $35 \%$, v/v ethanol) from a column (90 $\times 3.5 \mathrm{~cm}$ ) of charcoal (BDH; acid-washed)/Celite $(1: 1, \mathrm{w} / \mathrm{w})$.

Isoelectric focusing. Separations were performed in an LKB electrofocusing column $(110 \mathrm{ml})$. After focusing at $5^{\circ} \mathrm{C}$, the column was emptied at a rate of $120 \mathrm{ml} \mathrm{h}^{-1}$. Fractions $(2 \mathrm{ml})$ were collected, and the $\mathrm{pH}$ of each was measured at $5{ }^{\circ} \mathrm{C}$ with a Corning-Eel pH meter fitted with a combination electrode.

Enzyme assays. $C M$-cellulase activity. CM-cellulase activity was measured by the reducing-sugar method using modified Park-Johnson reagent, described previously (Wood \& McCrae, 1972).

Activity against cotton. Dewaxed cotton ( 2 or $20 \mathrm{mg}$ ) was incubated for $7 \mathrm{~d}(2 \mathrm{mg}$ cotton) or $18 \mathrm{~h}(20 \mathrm{mg})$ and the activity calculated as previously described (Wood, 1969). A $1 \mathrm{ml}$ volume of the $20-80 \%$ saturated $\left(\mathrm{NH}_{4}\right)_{2} \mathrm{SO}_{4}$ fraction, diluted 50 -fold, solubilized $1.4 \mathrm{mg}$ of the $2 \mathrm{mg}$ sample of cotton under these conditions.

Protease. Proteolytic activity was assayed with casein as substrate (Kunitz, 1947).

$\beta$-Glucosidase. $\beta$-Glucosidase was measured with $o$-nitrophenyl- $\beta$-glucopyranoside as substrate by the method already described (Wood, 1968).

Other assays. Reducing sugars were measured by the Nelson-Somogyi method (Nelson, 1952), D-glucose by a modified D-glucose oxidase method (Lloyd \& Whelan, 1969) and total sugar by the phenol-sulphuric acid method (Dubois et al., 1956). In each case the reagents were calibrated against D-glucose. Protein was determined by the Lowry method with crystalline bovine serum albumin used as the standard. In some of the fractionations the protein content was estimated from the $A_{280}$.

$T L C$. Thin-layer plates (Kieselgel G) were developed (two ascents) with ethyl acetate/propan-2-ol/water $(18: 13: 9$, by vol.) and sprayed with silver nitrate or anisaldehyde/sulphuric acid (Stahl \& Kaltenbach, 1961).

\section{RESULTS}

Fractionation of the cellulase complex. The $\beta$-glucosidase activity in a $5 \mathrm{ml}$ sample of 100 -fold concentrated partially purified [ $20-80 \%$ saturated $\left(\mathrm{NH}_{4}\right)_{2} \mathrm{SO}_{4}$ fraction] cell-free culture filtrate was separated from a low molecular weight endo- $\beta-(1 \rightarrow 4)$-glucanase component by gel filtration on a column $(2.5 \times 87.5 \mathrm{~cm})$ of Ultrogel AcA 44, and from cellobiohydrolase activity by ionexchange chromatography on DEAE-Sepharose equilibrated with $0 \cdot 1 \mathrm{M}-\mathrm{NaOH} /$ acetic acid buffer, pH 5.0 (Wood \& McCrae, 1978). The $\beta$-glucosidase and high molecular weight endo$(1 \rightarrow 4)$ - $\beta$-glucanase components, which were not adsorbed on the ion-exchange medium under such starting conditions, were precipitated with $\left(\mathrm{NH}_{4}\right)_{2} \mathrm{SO}_{4}$, desalted on a column of Sephadex G-25 equilibrated with $0.01 \mathrm{M}$-ammonium acetate and freeze-dried. A column $(27 \times 1.5 \mathrm{~cm})$ of SE-Sephadex equilibrated with $0.01 \mathrm{M}$-sodium succinate buffer, $\mathrm{pH} 4.5$, was used to separate $\beta$ glucosidase from the bulk of the endo-( $1 \rightarrow 4)-\beta$-glucanase as previously described (Wood, 1968; 


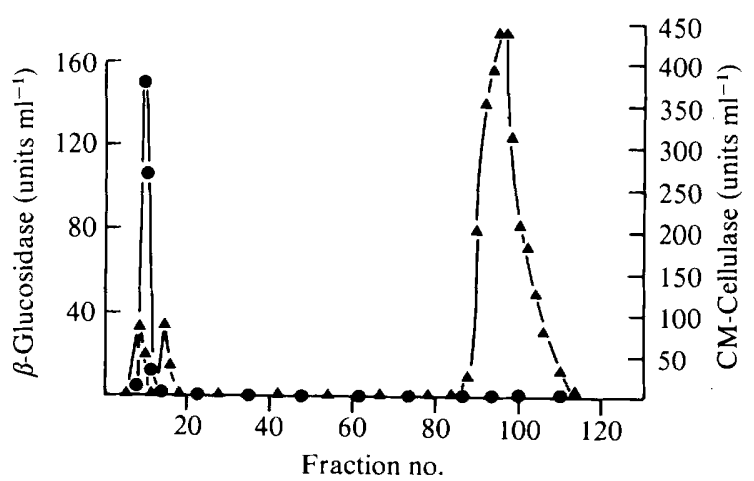

Fig. 1. Purification of $\beta$-glucosidase on a column of concanavalin A-Sepharose. The column $(1 \cdot 5 \times$ $27 \mathrm{~cm}$ ) was equilibrated with $0 \cdot 1 \mathrm{M}$-acetate buffer, $\mathrm{pH} 6 \cdot 0$ which contained $1 \mathrm{M}-\mathrm{NaCl}, 1 \mathrm{mM}-\mathrm{MnCl}_{2}$, $1 \mathrm{~mm}-\mathrm{CaCl}_{2}$ and $0.003 \mathrm{~mm}-\mathrm{NaN}_{3}$. The enzyme $(2 \mathrm{ml})$, which had been equilibrated by dialysis (collodion tube) against the same equilibrating buffer, was applied to the column in the cold room and then washed with the same buffer solution at $20 \mathrm{ml} \mathrm{h}^{-1}$. Fractions $(5 \mathrm{ml})$ were collected and assayed for $\beta$-glucosidase (O) and CM-cellulase $(\boldsymbol{\Lambda})$ activities. After tube 85 the column was eluted with a linear gradient of 0 to $0.5 \%(w / v) \alpha$-methyl-D-mannoside in the above buffer. The gradient was formed by an LKB Ultrograd.

Wood \& McCrae, 1978). Fractions rich in $\beta$-glucosidase were pooled, diluted with $2 \%(\mathrm{v} / \mathrm{v})$ carrier ampholyte, $\mathrm{pH}$ range $4-6$, and subjected to isoelectric focusing.

A more convenient method of separating $\beta$-glucosidase from the high molecular weight endo$(1 \rightarrow 4)-\beta$-glucanase activity was by using a column of concanavalin A-Sepharose (Fig. 1). Under the conditions given in the legend to Fig. $1, \beta$-glucosidase passed straight through the column

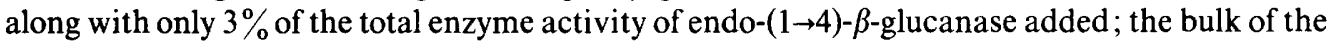
endo-( $1 \rightarrow 4)$ - $\beta$-glucanase was finalty eluted with $\alpha$-D-mannoside. Recovery of $\beta$-glucosidase from the concanavalin A-Sepharose column was normally in excess of $90 \%$.

Separation and purification of $\beta$-glucosidase components. A typical distribution of $\beta$-glucosidase, $\mathrm{CM}$-cellulase and protein from an electrofocusing experiment using carrier ampholyte, $\mathrm{pH}$ range 4-6, is shown in Fig. 2. $\beta$-Glucosidase ${ }_{1}$ (which had a $\mathrm{pI}$ of 5.53) was virtually free from CM-cellulase activity. $\beta$-Glucosidase ${ }_{2}$ (pI 5.85) differed from $\beta$-glucosidase ${ }_{1}$ in this latter respect, but it could be purified further by the isoelectric focusing technique (Fig. 3), when a small CM-cellulase component (pI 6.28) was separated using carrier ampholyte covering a higher $\mathrm{pH}$ range (5-7). Both $\beta$-glucosidase ${ }_{1}$ and $\beta$-glucosidase - $_{2}$ were purified by re-runs in ampholyte pH 4-6 (Fig. 4) and $\mathrm{pH}$ 5-7 (data not shown), respectively.

Purified in this way, $\beta$-glucosidase ${ }_{1}$ was free from CM-cellulase activity. $\beta$-Glucosidase ${ }_{2}$ was, however, still able to attack [0.1\% total increase in reducing power (glucose equivalent) in $1 \mathrm{~h}]$ CM-cellulose with a degree of substitution of 0.5 , but a more highly substituted sample of CMcellulose (degree of substitution 0.7 ) was not a substrate.

Purified $\beta$-glucosidase $_{1}$ and $\beta$-glucosidase 2 amounted to $0 \cdot 14 \%(\mathrm{w} / \mathrm{w})$ and $0.39 \%(\mathrm{w} / \mathrm{w})$, respectively, of the total protein found in the crude cell-free culture filtrate, as determined by the Lowry method. Many purification runs were necessary to prepare significant amounts of purified enzyme as it was found impossible to scale-up the purification and still achieve the same degree of purity.

Molecular weight of the enzymes. The molecular weight of the purified enzymes was estimated by gel filtration through a column of Ultrogel AcA 44 calibrated with the standard proteins cytochrome $c$ (mol. wt 12400), chymotrypsinogen (25800), ovalbumin (45000), bovine serum albumin (67000) and bovine $\gamma$-globulin (160000). A linear relationship was obtained when the elution volumes of the standard proteins were plotted against the log of the molecular weight. The molecular weights of both enzymes were estimated from this graph to be 39800 . 


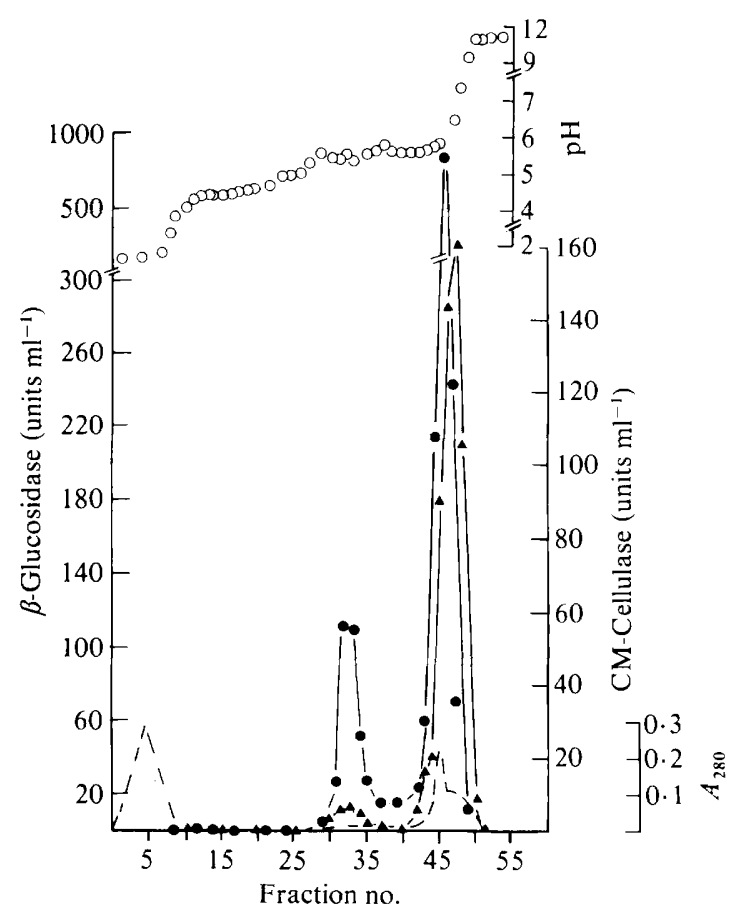

Fig. 2. Separation of $\beta$-glucosidase ${ }_{1}$ and $\beta$-glucosidase , $_{2}$ by isoelectric focusing. The $\beta$-glucosidase-rich component $(20 \mathrm{ml})$ isolated from $T$. koningii cellulase by chromatography on Ultrogel AcA 44, DEAESephadex and SE-Sephadex as described in the text, was mixed with $10 \mathrm{ml}$ carrier ampholyte (pH 4-6) and added to an isoelectric focusing column of $110 \mathrm{ml}$ capacity. After focusing for $70 \mathrm{~h}(600 \mathrm{~V}, 3 \mathrm{~mA}$ at the start $; 00 \mathrm{~V}, 1 \mathrm{~mA}$ at the end of the run) the column was emptied and the fractions $(2 \mathrm{ml})$ assayed:

- $\beta$-glucosidase activity; $\boldsymbol{\Delta}, \mathrm{CM}$-cellulase activity; $-\cdots, \boldsymbol{A}_{280}$ (protein content); $\mathrm{O}, \mathrm{pH}$.

Carbohydrate content of the enzymes. Using the phenol-sulphuric acid method (Dubois et al., 1956) for measuring carbohydrate and the Lowry method for estimating protein, $\beta$-glucosidase ${ }_{2}$, which had been purified by isoelectric focusing, was found to be associated with approximately $2 \%$ carbohydrate (glucose equivalent). However in view of the small amounts of protein obtained from the isoelectric focusing, this value must be regarded as very approximate. $\beta$ Glucosidase $_{1}$ purified by isoelectric focusing appeared to be free from carbohydrate.

When $\beta$-glucosidase activity from another cell-free cellulase preparation of $T$. koningii (cultured as above) was separated from the endo- and exo-( $1 \rightarrow 4)$ - $\beta$-glucanase activities using a column of concanavalin A-Sepharose (Fig. 1) and subsequently fractionated into $\beta$-glucosidase ${ }_{1}$ and $\beta$-glucosidase ${ }_{2}$ on an isoelectric focusing column, neither component appeared to be associated with carbohydrate.

Transferase activity of the enzymes. With high concentrations of cellobiose $(5 \%, w / v)$, large amounts of a component with the same mobility as authentic cellotriose were detected by TLC on silica gel plates; traces of a slower moving component travelling at the same speed as authentic cellotetraose appeared on prolonged $(5 \mathrm{~h})$ incubation.

Specificity of $\beta$-glucosidase components. Both $\beta$-glucosidases acted rapidly on both $o$ - and $p$ nitrophenyl- $\beta$-glucosides and more slowly on the aryl- $\beta$-glucosides salicin and arbutin (Table 1 ). The only alkyl- $\beta$-glucoside tested, methyl- $\beta$-glucoside, was not a substrate for either component. Both $\beta$-glucosidases acted on all the various $\beta$-glucosyl glucoses, although at markedly different rates (Table 2$)$. The activity on sophorose $(\beta-1 \rightarrow 2$-diglucose) or laminaribiose ( $\beta$-1 $\rightarrow 3$-diglucose), for example, was approximately four times that shown on gentiobiose $(\beta$-1 $\rightarrow 6$-diglucose). Cellobiose was attacked relatively slowly by both components.

Effect of heat. The effect of heat on $\beta$-glucosidase ${ }_{1}$ and $\beta$-glucosidase ${ }_{2}$ was almost identical under the conditions tested. When the enzymes were heated in the absence of substrate for 


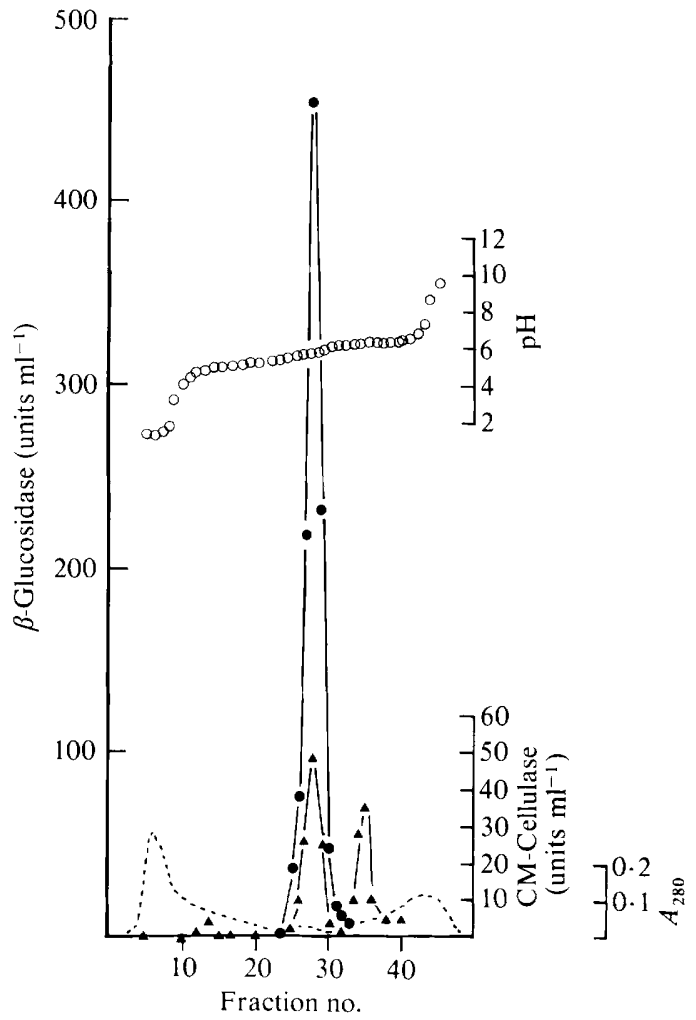

Fig. 3. Purification of $\beta$-glucosidase, by isoelectric focusing. Fractions $42-50$ (Fig. 2) were pooled, concentrated to $10 \mathrm{ml}$ on an Amicon cell using a PM-10 membrane, diluted with $10 \mathrm{ml} 2 \%(\mathrm{v} / \mathrm{v})$ carrier ampholyte solution ( $\mathrm{pH} \mathrm{5-7)} \mathrm{and} \mathrm{re-focused} \mathrm{using} \mathrm{the} \mathrm{same} \mathrm{column} \mathrm{and} \mathrm{conditions} \mathrm{listed} \mathrm{previously}$ (Fig. 2). Fractions ( $2 \mathrm{ml}$ ) were assayed: $\boldsymbol{O}, \beta$-glucosidase activity; $\boldsymbol{\Lambda}$, CM-cellulase activity; --- , $\boldsymbol{A}_{280}$ (protein content); $\mathrm{O}, \mathrm{pH}$.

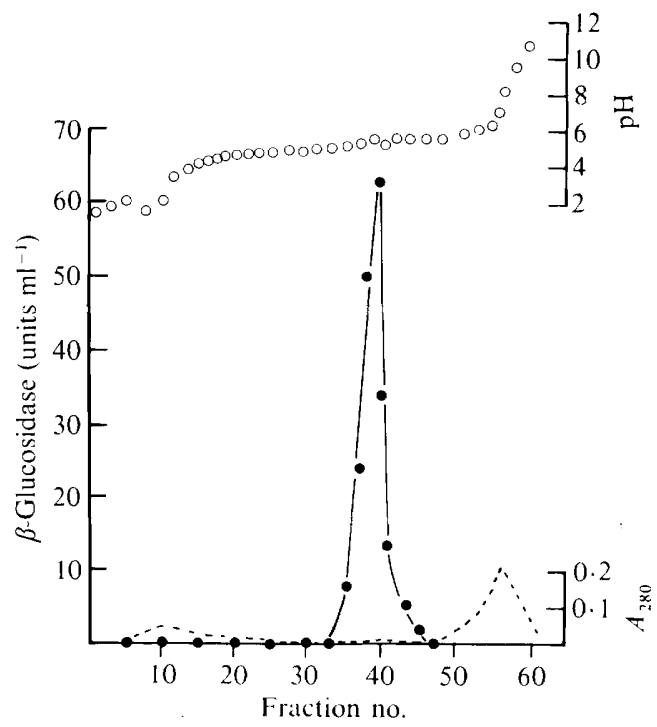

Fig. 4. Purification of $\beta$-glucosidase, by isoelectric focusing. Fractions $30-35$ (Fig. 2) were pooled $(54 \mathrm{ml})$, concentrated in an Amicon cell using a PM-10 membrane, diluted with $10 \mathrm{ml}$ of $2 \%(\mathrm{v} / \mathrm{v})$ carrier ampholyte solution ( $\mathrm{pH} \mathrm{4-6)}$ and added to the $100 \mathrm{ml} \mathrm{LKB}$ electrofocusing column. The voltage at the end of the run $(40 \mathrm{~h})$ was $810 \mathrm{~V}$ and current $0.5 \mathrm{~mA}$. The contents of the column were collected $(2 \mathrm{ml})$ and assayed: $-\beta$-glucosidase activity:---, $A_{280}$ (protein content); $\mathrm{O}, \mathrm{pH}$. 
Table 1. Hydrolysis of different glucosides by the $\beta$-glucosidase components

The reaction mixture contained $0.5 \mathrm{ml}$ of a solution of the substrate $(5 \mathrm{~mm}), 0.5 \mathrm{ml} 0.2 \mathrm{M}$-sodium acetate buffer (pH 5.0), $1.0 \mathrm{ml}$ enzyme, and water to give a total volume of $2 \mathrm{ml}$. Incubation was for $1 \mathrm{~h}$ at $37^{\circ} \mathrm{C}$, after which the glucose released was estimated by the method of Nelson (1952).

\begin{tabular}{|c|c|c|}
\hline \multirow[b]{2}{*}{ Glucoside } & \multicolumn{2}{|c|}{ Glucose released $(\mu \mathrm{g})$} \\
\hline & $\beta$-Glucosic & ucosidase $_{2}$ \\
\hline $\begin{array}{l}o \text {-Nitrophenyl- } \beta \text {-glucoside } \\
\text { (aryl- } \beta \text {-glucoside) }\end{array}$ & 80 & 70 \\
\hline $\begin{array}{l}p \text {-Nitrophenyl- } \beta \text {-glucoside } \\
\text { (aryl- } \beta \text {-glucoside) }\end{array}$ & 213 & 193 \\
\hline $\begin{array}{r}\text { Methyl- } \beta \text {-glucoside } \\
\text { (alkyl- } \beta \text {-glucoside) }\end{array}$ & 0 & 0 \\
\hline $\begin{array}{l}\text { Phloridzin (phloritin- } \beta \text {-glucoside) } \\
\text { (aryl- } \beta \text {-glucoside) }\end{array}$ & 0 & 0 \\
\hline $\begin{array}{l}\text { Amygdalin } \\
\text { (aryl- } \beta \text {-gentiobioside) }\end{array}$ & 12 & NT \\
\hline $\begin{array}{l}\text { Salicin (2-hydroxymethylphenyl- } \beta \text {-glucopyranoside) } \\
\text { (aryl- } \beta \text {-glucoside) }\end{array}$ & 27 & 25 \\
\hline $\begin{array}{l}\text { Arbutin (hydroquinone- } \beta \text {-glucopyranoside) } \\
\text { (aryl- } \beta \text {-glucoside) }\end{array}$ & 36 & 30 \\
\hline
\end{tabular}

Table 2. Relative activities of $\beta$-glucosidase ${ }_{1}$ and $\beta$-glucosidase ${ }_{2}$ on $\beta$-linked diglucoses

The enzymes used were those separated by isoelectric focusing. The assay consisted of approximately $1 \mathrm{~mm}$-substrate, $0.5 \mathrm{ml} 0.1 \mathrm{M}$-sodium acetate buffer $\mathrm{pH} 5 \cdot 0$, and enzyme plus water to give a total volume of $1 \mathrm{ml}$. After $30 \mathrm{~min}$ incubation at $37^{\circ} \mathrm{C}$ the glucose released was measured by the glucose oxidase method (see Methods); 5 units of $o$-nitrophenyl- $\beta$-glucosidase were used in each assay.

\begin{tabular}{lccc}
\multicolumn{1}{c}{ Substrate } & & $\overbrace{\beta \text {-Glucosidase }}{ }_{1} \beta$-Glucosidase \\
\end{tabular}

Table 3. Michaelis constants of the $\beta$-glucosidase components

\begin{tabular}{|c|c|c|}
\hline \multirow{4}{*}{$\begin{array}{l}\text { Substrate } \\
o \text {-Nitrophenyl- } \beta \text {-glucoside }\end{array}$} & \multicolumn{2}{|c|}{$K_{\mathrm{m}}(\mathrm{mM})^{*}$} \\
\hline & $\beta$-Glucosidase ${ }_{1}$ & $\beta$-Glucosidase ${ }_{2}$ \\
\hline & $0.37 \pm 0.04$ & $0.85 \pm 0.03$ \\
\hline & $1.18 \pm 0.09$ & $0.86 \pm$ \\
\hline Cellotriose & $5.1 \pm 0.22$ & $7.1 \pm 0.33$ \\
\hline Cellotetraose & $2.38 \pm 0.44$ & $4.0 \pm 0.4$ \\
\hline Cellopentaose & $1.51 \pm 0.04$ & $2.19 \pm 0.06$ \\
\hline
\end{tabular}

30 min at $45^{\circ} \mathrm{C}$, at $\mathrm{pH}$ values between 4 and 6 , no loss of activity was observed when the $\mathrm{pH}$ was below 4.5 ; at $\mathrm{pH} 6.0$ approximately $60 \%$ of the original activity was lost. At $\mathrm{pH} 5.0$ the enzymes were stable for at least $30 \mathrm{~min}$ at temperatures less than $50^{\circ} \mathrm{C}$; the stability fell dramatically at $65^{\circ} \mathrm{C}$ and at $70^{\circ} \mathrm{C}$ the enzymes were completely inactivated. 
$K_{m}$ and $K_{i}$ values. The two enzymes purified by isoelectric focusing were used for the calculation of $K_{\mathrm{m}}$ and $K_{\mathrm{i}}$ values using Lineweaver-Burk plots; $K_{\mathrm{m}}$ values for the aryl- $\beta$-glucoside, cellobiose and the soluble, short-chain cello-oligosaccharides, cellotriose, cellotetraose and cellopentaose are listed in Table 3 . The affinity of $\beta$-glucosidase ${ }_{1}$ for the aryl- $\beta$ glucoside was much higher than that of $\beta$-glucosidase ${ }_{2}$.

The effect of substrate concentration on the kinetics of hydrolysis of the soluble trisaccharides, tetrasaccharides and pentasaccharides by $\beta$-glucosidase ${ }_{1}$ and $\beta$-glucosidase g $_{2}$ was tested using concentrations up to $2.4 \mathrm{~mm}$. The two enzymes were affected in a similar fashion. Substrate inhibition occurred with relatively low concentrations of cellotriose $(0.6 \mathrm{mM})$, cellotetraose $(0.2 \mathrm{~mm})$ or cellopentaose $(0.4 \mathrm{~mm})$. However, with cellobiose as substrate, concentrations of approximately $10 \mathrm{~mm}$ were required before significant inhibition was observed. $o$-Nitrophenyl- $\beta$-glucoside was inhibitory to both $\beta$-glucosidases at relatively low concentrations $(0.8 \mathrm{~mm})$. The inhibition constant $\left(K_{\mathrm{i}}, \pm\right.$ the S.D. $)$ for gluconolactone with $o$ nitrophenyl- $\beta$-glucoside as substrate was $1.8 \pm 0.08 \mu \mathrm{M}$ in the case of $\beta$-glucosidase ${ }_{1}$ and $1.17 \pm$ $0.05 \mu \mathrm{M}$ in the case of $\beta$-glucosidase ${ }_{2}$; glucose was less inhibitory, values of $K_{\mathrm{i}}$ being $1.05 \pm 0.07$ $\mathrm{mm}$ and $0.66 \pm 0.04 \mathrm{mM}$, respectively. Inhibition was of the competitive type in all cases.

Synergism between the $\beta$-glucosidase components and the other enzymes of the cellulase complex in solubilizing various celluloses. Synergism was apparent between the $\beta$-glucosidases and either the endo- $(1 \rightarrow 4)-\beta$-glucanase or the cellobiohydrolase. However, the degree of co-operation shown depended on the substrate as well as the particular $\beta$-glucosidase used. With cotton fibre as substrate both $\beta$-glucosidases co-operated with the cellobiohydrolase but not with the endo$(1 \rightarrow 4)$ - $\beta$-glucanase (Table 4). With $\mathrm{H}_{3} \mathrm{PO}_{4}$-swollen cellulose, synergism was apparent with all combinations of enzyme tested, although the degree to which the enzymes co-operated varied considerably. When endo-( $1 \rightarrow 4)-\beta$-glucanase was acting in admixture with either of the $\beta$ glucosidases, essentially the same amount of hydrolysis was effected. However, mixtures of cellobiohydrolase $(200 \mu \mathrm{g}$ protein) and $\beta$-glucosidase (10 units) acted differently. In $24 \mathrm{~h}, \beta$ glucosidase $_{1}\left(37^{\circ} \mathrm{C}, 5 \mathrm{ml}\right.$ reaction mixture) produced a considerably greater breakdown of $10 \mathrm{mg} \mathrm{H}_{3} \mathrm{PO}_{4}$-swollen cellulose (approximately $30 \%$ by wt) when acting in conjunction with cellobiohydrolase than did $\beta$-glucosidase ${ }_{2}$ (approximately $20 \%$ by wt).

Both $\beta$-glucosidases co-operated to approximately the same extent with a mixture of cellobiohydrolase and endoglucanase to solubilize cotton fibre (Table 4).

Table 4. Synergism between the $\beta$-glucosidases of $T$. koningii and the other hydrolytic enzymes of the cellulase system in solubilizing the cellulose in cotton fibre

$\beta$-Glucosidase - $_{1}$ and $\beta$-glucosidase - $_{2}$ were purified as described in the text, after separation from cellobiohydrolase and endo-(1-4)- $\beta$-glucanase by chromatography on concanavalin A-Sepharose. Cellobiohydrolase and endo-( $1 \rightarrow 4)-\beta$-glucanase were then separated by ion-exchange chromatography on DEAE-Sepharose. The assays contained cellobiohydrolase $(200 \mu \mathrm{g})$, endo- $(1 \rightarrow 4)-\beta$-glucanase $(100 \mu \mathrm{g})$ and $\beta$-glucosides (10 units of $o$-nitrophenyl- $\beta$-glucosidase). The activity against cotton ( $2 \mathrm{mg}$ ) was determined by estimating the residual cellulose left after $7 \mathrm{~d}$ incubation (see text); the weight of cellulose solubilized was calculated by difference and expressed as a percentage of the initial weight.

Enzyme

$\beta$-Glucosidase ${ }_{1}$

$\beta$-Glucosidase

Cellobiohydrolase

Endo-( $1 \rightarrow 4)-\beta$-glucanase

Endo- $(1 \rightarrow 4)-\beta$-glucanase + cellobiohydrolase

$\beta$-Glucosidase - $_{1}+$ cellobiohydrolase

$\beta$-Glucosidase ${ }_{2}+$ cellobiohydrolase

$\beta$-Glucosidase ${ }_{1}+$ endoglucanase

$\beta$-Glucosidase ${ }_{2}+$ endoglucanase

$\beta$-Glucosidase - $_{1}+$ cellobiohydrolase + endoglucanase

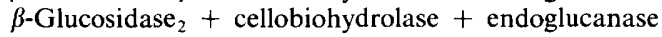

Solubilization

$(\%)$

0

0

1

6
53

20

19

6

5
68

66 


\section{DISCUSSION}

$\beta$-Glucosidases appear to exist in multiple forms in many cellulase systems. In the case of Stachybotrys atra $\beta$-glucosidase (Jermyn, 1962) the multiplicity has been ascribed to the formation of a number of complexes between a single enzyme and a number of polysaccharides, but modification of the enzymes by proteolysis has been tentatively suggested to be the cause of the apparent heterogeneity of the $\beta$-glucosidase of Sporotrichum pulverulentum (Deshpande et al., 1978). Neither of these explanations would seem to describe satisfactorily the reason for the apparent multuple nature of the $\beta$-glucosidase of $T$. koningii, since $(a)$ the crude cell-free culture filtrate seemed to be free from proteolytic activity under the assay conditions used, and $(b)$ after thorough purification the two $\beta$-glucosidase components did not seem to be associated with significant amounts of carbohydrate. However, it is still possible that one or both of the $\beta$ glucosidases are artefacts reflecting small structural changes in the protein during culture, isolation or purification. The existence of an association dissociation phenomenon similar to that found for the $\beta$-glucosidase of Botryodiplodia theobromae (Umezurike, 1975), is another possibility that cannot be ruled out; in these circumstances the $\beta$-glucosidases would in effect be subunits of a large molecule.

The molecular weights of the $\beta$-glucosidases of $T$. koningii (39800) compare with values of 76000 and 47000 reported for Trichoderma viride $\beta$-glucosidases (Li et al., 1965; Berghem \& Pettersson, 1974), but are much smaller than those of Fusarium solani (400000; Wood, 1971), Aspergillus wentii (170000; Legler, 1967) and Sporotrichum pulverulentum (165000-182000; Deshpande et al., 1978). Umezurike (1975) contends that there is a similarity in the $\beta$ glucosidases from various sources in terms of molecular weight and concludes that all $\beta$ glucosidases are aggregates of a monomer with a molecular weight of approximately 40000 . Clearly, this is highly speculative, but it is noteworthy that the $\beta$-glucosidases of $T$. koningii have a molecular weight similar to the basic unit envisaged.

The whole question of the number of enzyme components synthesized by the cellulolytic fungus for efficient hydrolysis of native cellulose is currently the subject of some debate in the literature. This applies as much to the $\beta$-glucosidases as it does to the enzymes with exo- $(1 \rightarrow 4)-\beta$ glucanase and endo-( $1 \rightarrow 4)-\beta$-glucanase activities which are required for the conversion of insoluble cellulose to soluble sugars. Under the conditions used in this study, $T$. koningii $\beta$ glucosidase $_{1}$ and $\beta$-glucosidase $_{2}$ would appear to be more or less identical in the extent to which they co-operate with the exo- $(1 \rightarrow 4)-\beta$-glucanase (cellobiohydrolase) and/or endo- $(1 \rightarrow 4)-\beta$ glucanase of the same cellulase system in hydrolysing native cellulose (e.g. cotton cellulose). This has led us in the past to conclude tentatively that the $\beta$-glucosidases were isoenzymes. However, a more detailed examination of the properties of the $\beta$-glucosidases now shows that they do differ somewhat in terms of $(a)$ their capacities for acting co-operatively with the cellobiohydrolase to solubilize $\mathrm{H}_{3} \mathrm{PO}_{4}$-swollen cellulose, and $(b)$ their affinities for cellobiose, cellotriose, cellotetraose and cellopentaose. Clearly, since cellobiose, in particular, is a potent inhibitor of cellulase action (Halliwell \& Griffin, 1973; Wood \& McCrae, 1975), it is possible that under some test conditions the variation in affinity of the $\beta$-glucosidase for the dimer would be manifested in different rates of hydrolysis of cellulose when the $\beta$-glucosidase was acting in admixture with the other members of the cellulase system.

The affinities of the two $\beta$-glucosidases of $T$. koningii for cellobiose ( $K_{\mathrm{m}}$ values $1.18 \mathrm{~mm}$ and $0.86 \mathrm{~mm})$ were very similar to that displayed by the $\beta$-glucosidase of Trichoderma viride isolated by Berghem \& Pettersson (1974) $\left(K_{\mathrm{m}} 1.5 \mathrm{~mm}\right)$ and Emert et al. (1974) $\left(K_{\mathrm{m}} 1.8 \mathrm{mM}\right)$ and the $\beta$ glucosidase of Aspergillus phoenicis $\left(K_{\mathrm{m}} 0.76 \mathrm{~mm}\right.$ ) studied by Sternberg et al. (1977). However, $T$. koningii $\beta$-glucosidase does differ from $T$. viride $\beta$-glucosidase in that the $K_{\mathrm{m}}$ values for longerchain oligosaccharides, such as the trimer and the tetramer, are higher than that for the dimer; this would indicate that $T$. koningii $\beta$-glucosidase has a lower affinity for these oligomers than $T$. viride $\beta$-glucosidase.

The T. koningii $\beta$-glucosidases are similar to the $\beta$-glucosidases of Sporotrichum pulverulentum (Deshpande et al., 1978), Aspergillus phoenicis (Sternberg et al., 1977), Trichoderma viride (Berghem \& Pettersson, 1974) and Trichoderma reesei (Sternberg et al., 1977) in that they can hydrolyse both aryl- $\beta$-glucosides and cellobiose. However, while such substrate specificity is 
common, it is not universal. Thus, the aryl- $\beta$-glucosidases from Stachybotrys atra (Jermyn, 1962) cannot attack cellobiose. A broad substrate specificity is characteristic of $\beta$-glucosidases, however, and this property has been used to distinguish the $\beta$-glucosidases from the exoglucanases (Reese et al., 1968). Typically, the $\beta$-glucosidases of $T$. koningii have the ability to hydrolyse other $\beta$-linked dimers of glucose, albeit at widely varying rates. Sophorose and laminaribiose are better substrates than cellobiose or gentiobiose, and in this respect the $\beta$ glucosidases are similar to the $\beta$-glucosidase of Aspergillus fumigatus (Rudick \& Elbein, 1973). The $\beta$-glucosidases of Aspergillus phoenicis (Sternberg et al., 1977) and Aspergillus niger (Reese $e t$ al., 1968) differ, however, in that activity on cellobiose is greatest.

\section{REFERENCES}

BeJA DA Costa, M. \& VAN Uden, N. (1980). Use of 2 deoxyglucose in the selective isolation of mutants of Trichoderma reesei with enhanced $\beta$-glucosidase production. Biotechnology and Bioengineering 23, 2429-2430.

Berghem, L. E. R. \& Pettersson, L. G. (1974). The mechanism of enzymatic degradation. Isolation and some properties of a $\beta$-glucosidase of Trichoderma koningii. European Journal of Biochemistry 46, 295305.

Berghem, L. E. R., Pettersson, L. G. \& AxioFREDRIKSSON, U-B. (1975). The mechanism of enzymatic cellulose degradation. Characterization and enzymatic properties of a $\beta$-1,4-glucan cellobiohydrolase from Trichoderma viride. European Journal of Biochemistry 53, 55-62.

Deshpande, V., Eriksson, K-E. \& Pettersson, B. (1978). Production, purification and partial characterization of $1,4-\beta$-glucosidase enzymes from Sporotrichum pulverulentum. European Journal of Biochemistry 90, 191-198.

Dubois, M., Gilles, K., Hamilton, J. K., Rebers, P. A. \& SMITH, F. (1956). Colorimetric method for determination of sugars and related substances. Analytical Chemistry 28, 350-356.

Emert, G. H., Gum, E. K., LANG, J. A., LiU, T. U. \& Brown, R. D. (1974). Cellulases. In Food Related Enzymes, pp. 79-100. Edited by J. Whitaker. Washington D.C.: American Chemical Society.

GonG, C.-S., Ladisch, M. R. \& TSAO, G. T. (1979). Biosynthesis, purification and mode of action of cellulases by Trichoderma reesei. In Hydrolysis of Cellulose : Mechanisms of Enzymatic and Acid Catalysis, pp. 261-288. Edited by R. D. Brown \& L. Jurasek. Washington D.C.: American Chemical Society.

Halliwell, G. \& GRIFFin, M. (1973). The nature and mode of action of the cellulolytic component $C_{1}$ of Trichoderma koningii on native cellulose. Biochemical Journal 135, 587-594.

Jermyn, M. A. (1962). Fungal cellulases, X. Further purification of the $\beta$-glucosidase of Stachybotrys atra. Australian Journal of Biological Sciences 15, 769786.

Kunitz, M. (1947). Crystalline soybean trypsin inhibitor. II General properties. Journal of General Physiology 30, 291-294.

LEGLER, G. (1967). Action mechanism of glucosidesplitting enzymes II. Isolation and enzymic properties of two $\beta$-glucosidases from Aspergillus crentii. Hoppe-Seyler's Zeitschrift für physiologische Chemie 348, 1359-1366.
LI, L. H., Flora, R. M. \& King, K. W. (1965). Individual roles of cellulase components derived from Trichoderma viride. Archives of Biochemistry \& Biophysics 111, 439-447.

Lloyd, J. B. \& Whelan, W. J. (1969). An improved method for enzymatic determination of glucose in the presence of maltose. Analytical Biochemistry 30, 467-469.

Miller, G. L., Dean, J. \& Blum, R. (1960). A study of methods for preparing oligosaccharides from cellulose. Archives of Biochemistry and Biophysics 91, 2126

NELSON, N. (1952). A photometric adaptation of the Somogyi method for the determination of glucose. Journal of Biological Chemistry 153, 376-380.

Reese, E. T., Maguire, A. H. \& Parrish, F. W. (1968). Glucosidases and exo-glucanases. Canadian Journal of Biochemistry 46, 25-34.

Rudick, M. J. \& Elbein, A. D. (1973). Glycoprotein enzymes secreted by Aspergillus fumigatus. Journal of Biological Chemistry 248, 6506-6513.

STAHL, E. \& Kaltenbach, U. (1961). DünnschichtChromatographie. VI. Mitteilung. Spurenanalyse von Zuckergemischen auf Kieselgur G-Schichten. Journal of Chromatography 5, 351-352.

SternberG, D., ViJayakumar, P. \& Reese, E. T. (1977). $\beta$-Glucosidase: microbial production and effect on enzymatic hydrolysis of cellulose. Canadian Journal of Microbiology 23, 139-147.

UMEZURIKE, G. M. (1975). The subunit structure of $\beta$ glucosidase from Botryodiplodia theobromae Pat. Biochemical Journal 145, 361-368.

WoOD, T. M. (1968). Cellulolytic enzyme system of Trichoderma koningii. Separation of components attacking native cotton. Biochemical Journal 109 , 217-227.

Wood, T. M. (1969). The cellulase of Fusarium solani: resolution of the enzyme complex. Biochemical Journal 115, 457-464.

Wood, T. M. (1971). The cellulase of Fusarium solani. Purification and specificity of the $\beta-(1 \rightarrow 4)$-glucanase and the $\beta$-D-glucosidase components. Biochemical Journal 121, 353-362.

Wood, T. M. (1972). The $C_{1}$ component of the cellulase complex. In Proceedings of the 4th International Fermentation Symposium, Kyoto, Japan, pp. 711-718. Edited by G. Terui. Osaka: Society of Fermentation Technology.

Wood, T. M. \& MCCrae, S. I. (1972). The purification and properties of the $C_{1}$ component of Trichoderma koningii cellulase. Biochemical Journal 128, 11831192. 
WoOd, T. M. \& MCCraE, S. I. (1975). The cellulase complex of Trichoderma koningii. In Symposium on Enzymatic Hydrolysis of Cellulose, pp. 231-254. Edited by $M$. Bailey, T.-M. Enari, M. Linko. Aulanko, Finland: SITRA.

WoOd, T. M. \& MCCraE, S. I. (1977a). The mechanism of cellulase action with particular reference to the $\mathrm{C}_{1}$ component. In Proceedings of Bioconversion Symposium, IIT, Delhi, pp. 111-141. Edited by T. K. Ghose. Faridabad, India: Thomson Press.
Wood, T. M. \& MCCrae, S. I. (1977b). Cellulase from Fusarium solani: purification and properties of the $\mathrm{C}_{1}$ component. Carbohydrate Research 57, 117-133. WOOD, T. M. \& MCCRAE, S. I. (1978). The cellulase of Trichoderma koningii. Purification and properties of some endoglucanase components with special reference to their action on cellulose when acting alone and in synergism with the cellobiohydrolase. Biochemical Journal 171, 61-72. 